\title{
BRINQUEDO PROIBIDO (1952): NO TERRENO INFINDÁVEL DAS CRUZINHAS, DAS PEDRAS, DOS ANIMAIS, DAS FLORES, DOS CACOS DE LOUÇA E DOS CARAMUJOS...HAVIA INFÂNCIA
}

\author{
BRINQUEDO PROIBIDO (1952): EN EL TERRENO INACABABLE DE LAS \\ CRUCECITAS, DE LAS PIEDRAS, DE LOS ANIMALES, DE LAS FLORES, DE \\ LOS PEDAZOS DE LOZA Y DE LOS CARAMUJOS... HABÍA INFANCIA
}

\author{
RECHIA, Karen Christine \\ krechia@gmail.com \\ UFSC/CED/CA - Colégio de Aplicação
}

\begin{abstract}
RESUMO Paulette é uma garotinha que tem seus pais mortos num ataque durante a Segunda Guerra Mundial numa estrada em que caminham refugiados. Carregando seu cachorrinho morto - a única memória que ela pode carregar - chega numa fazenda francesa e faz amizade com o menino Michel. Juntos eles criam um cemitério para os animais mortos. O que se quer destacar é o jogo que se configura entre as duas crianças na e para a construção do cemitério: quanto mais cruzes e mais animais mortos, mais felicidade para Paulette. Michel quer agradá-la: esmaga a barata com o lápis, traduzindo em forma de um bombardeio sua própria percepção da guerra: "se queres enterrá-los, tem que estar mortos." Na constituição de locais narrativos há jogos que envolvem a vivência da guerra e seu imponderável.
\end{abstract}

PALAVRAS-CHAVE: Cinema. Guerra. Infância. Jogo.

RESUMEN Paulette es una niña cuyos padres murieron en un ataque durante la Segunda Guerra Mundial en una carretera de refugiados. Acarreando su perro muerto - la única memoria que ella puede llevar - llega en una hacienda francesa y se hace amiga de un niño que se llama Michel. Juntos crean un cementerio para los animales muertos. Lo que se quiere destacar es el juego que se configura entre los dos niños en y para la construcción del cementerio: cuantas más cruces y más animales muertos, más felicidad para Paulette. Michel quiere gustarle: aplasta la cucaracha con un lápiz, traduciendo en forma de bombardeo su propia percepción de la guerra: "si quieres enterrarlos, tienen que estar muertos". En la constitución de los lugares narrativos hay juegos que implican la vivencia de la guerra y su imponderable. ${ }^{1}$

PALABRAS-CLAVE: Cine. Guerra. Infancia. Juego.

Entre o formigário morto e gotejante e o formigário
denso e vivo, um intervalo: o tigre. Pode se mover
para evitá-lo, e o que se consegue é uma
imobilidade, na qual as relações endurecem e as
surras e as ameaças tornam-se a terra de uma
eterna reterritorialização, casa morta e gotejante.
Ou pode-se tomá-lo numa aliança, vencer o medo
e fugir do confinamento correndo o risco, pois os
"horrores renovados" são a vida em seu

${ }^{1}$ Agradeço a Jorge Larrosa pela tradução para o espanhol. 
movimento. Para Isabel, a vida é jogo, percursos, é a experimentação feita nos arranjos móveis de sua invenção, sem saber de antemão o que pode acontecer (GODOY, 2008, p. 269).

Este filme francês de $1952^{2}$ tem como pano de fundo a Segunda Guerra Mundial, mas precisamente o ano de 1940, no qual a França se rende ao poder nazista alemão. Após a invasão de Paris pelas tropas nazistas, o general francês Henri Pétain assina, em 22 de junho do mesmo ano um armistício com a Alemanha. Este armistício autorizava a ocupação de mais de metade do território francês. ${ }^{3}$ Por isso na primeira cena da película vemos uma migração de pessoas, carros e carroças por uma estrada vicinal, em algum lugar do interior da França. São pessoas em marcha, em fuga, aterrorizadas pelos esquadrões aéreos que despejam bombardeios em série.

Fig.1: Paulette e sua mãe.

\footnotetext{
${ }^{2}$ Dirigido por René Clément, conquistou várias importantes premiações, como o Prêmio Honorário de Melhor Filme Estrangeiro em 1953 (a categoria só foi criada oficialmente em 1957), melhor filme no Festival de Veneza em 1952 e no BAFTA em 1954. O filme originalmente seria um curta, mas algum tempo depois das primeiras filmagens foi decidido que um longa seria mais interessante.

${ }^{3} \mathrm{Em}$ Julho, Henri Pétain assumiu o cargo do governo de Vichy, a cidade que apoiou este governo. Pétain (1856-1951), que foi considerado herói militar durante a Primeira Guerra Mundial, toma uma atitude contrária ao permitir a ocupação alemã durante a Segunda Guerra Mundial. O governo de Vichy, colaboracionista, permitiu a prisão de judeus e de membros da resistência francesa, enviandoos para os campos de concentração. Para entender melhor o contexto, ver Pela vida dos outros. Disponível em: http://www.revistadehistoria.com.br/secao/capa/pela-vida-dos-outros. Acesso em: mai. De 2015.
} 


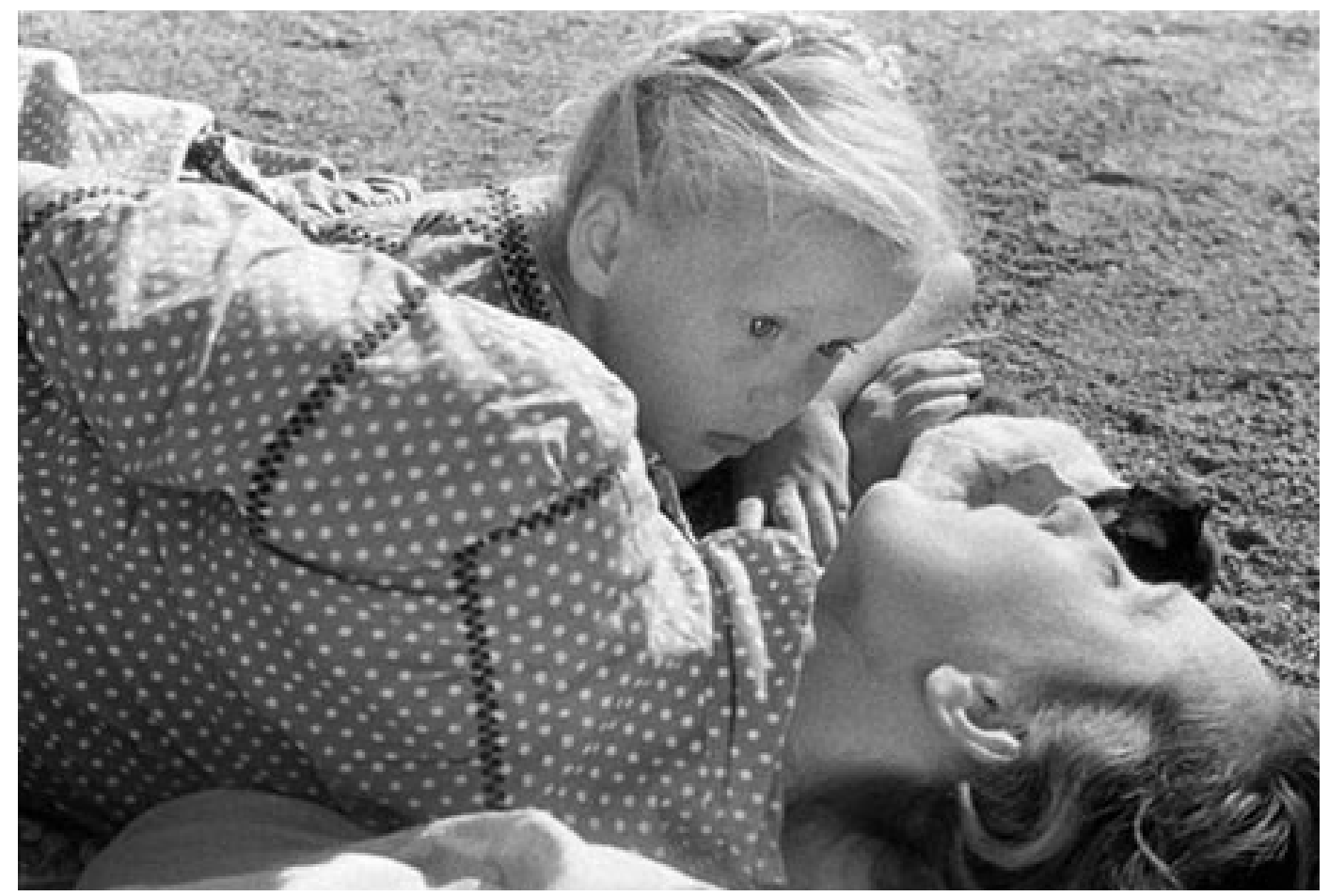

Fonte: <http://thefifiorganization.net/janus/forbidden-games/>. Acesso em: maio/2015.

Neste cenário de guerra, com as pessoas em marcha, somos apresentados a Paulette $^{4}$, seu cachorro Jock e seus pais, cujo carro quebra em meio ao caminho. Quando a menina vai atrás de Jock, que corre à frente, seus pais tentam resgatá-la. Ao deitarem no chão para protegê-la, o bombardeio os atinge (Fig.1). Assim começa a história que leva a garotinha, cuja idade gira em torno de seis anos no filme, a encontrar Michel $^{5}$, um garoto do campo, que convence sua família a acolhê-la. Aliás, o primeiro encontro entre os dois, quando Paulette está caminhando a esmo, depois de regatar seu cachorrinho morto no rio e Michel está atrás de uma vaca em fuga, já esboça as primeiras pistas sobre a forma como vão perceber e lidar com este mundo à sua volta (Fig.2).

Fig.2: Michel, Paulette e o cachorrinho Jock.

\footnotetext{
${ }^{4}$ Paulette é a atriz Brigitte Fossey, que à época tinha 6 anos de idade. Como curiosidade, os pais da menina a levaram ao teste, mesmo sabendo que a procura era por meninas entre 9 e 11 anos.

${ }^{5}$ Michel é o ator Georges Poujouly.
} 


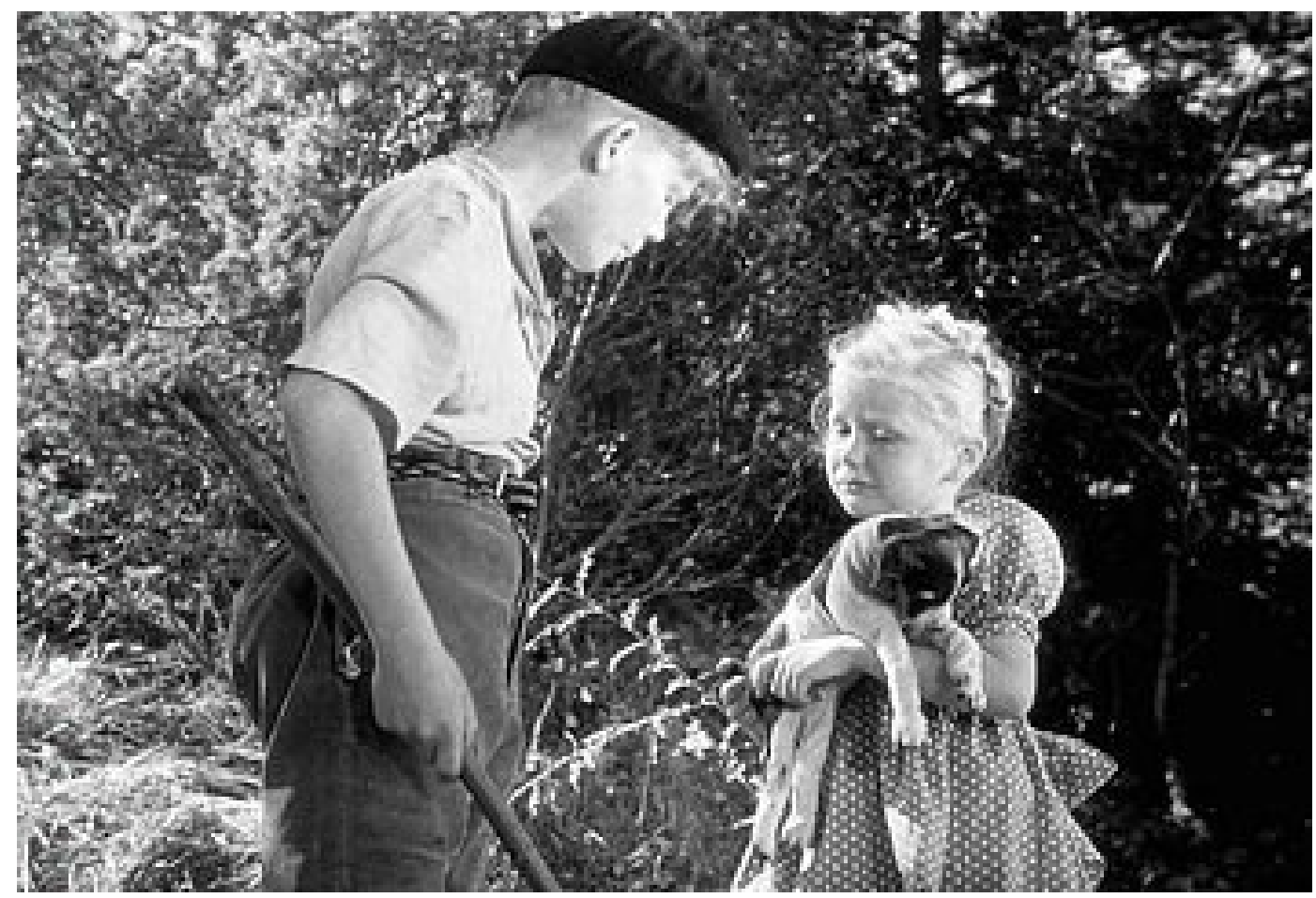

Fonte: http://dada.warped.com/movies/0707.html>. Acesso em: maio/2015.

- Onde está sua mãe? Pergunta Michel.

- Morta, responde Paulette.

- E seu pai?

- Morto.

- O meu não está e vai me bater se eu não pegar a vaca.

Antes de entrarmos - espectadores e leitores - no jogo das cenas propriamente dito, é importante que se faça uma consideração breve sobre infância e cinema. Já sabemos que o tempo do filme, assim como o tempo da infância, é outro, que protagonizar uma película com crianças pode nos trazer múltiplas possibilidades de olharmos para o mundo e que a forma como a linguagem cinematográfica as coloca em cena nos permite estabelecer certa relação com as coisas. Na apresentação de $A$ infância vai ao cinema, os organizadores vão mais além:

É como se o cinema não somente olhasse às crianças, mas tratasse de aproximar-se de uma mirada infantil, tentasse reproduzir, ou inventar, o olhar de criança. Algumas vezes o cinema dá a ver o mundo, o real, pelos 


\begin{abstract}
olhos de uma criança. Por exemplo, quando coloca a câmara na altura dos olhos de uma criança e quando são os olhos de uma criança que dão ao visível suas qualidades perceptivas ou emocionais. Somente o cinema é capaz de tal feito, na simplicidade de dois planos consecutivos: primeiro, uma criança que olha; logo, o que essa criança está olhando. E o silêncio, que diz tudo. (TEIXEIRA; LARROSA; LOPES, 2006, p.15).
\end{abstract}

Dessa forma, o filme em questão nos coloca o tempo todo neste duplo movimento do olhar infantil: que olha e o que está olhando. Inclusive os adultos geralmente são enquadrados nos planos abertos, pois os planos fechados acompanham os gestos e, é claro, o que se considera aqui como o jogo estabelecido entre os dois personagens. A câmera não só está a altura dos olhos das crianças, na maior parte das vezes, como está a olhar o que elas estão olhando, nos dando uma possibilidade de acessar este universo, através de sensações presentes ou (i) memoriais.

Como sabemos, brincar e jogar são sinônimos em várias línguas, ou melhor dizendo, brincar e jogar são definidos com uma mesma palavra (JARDIM, 2003, p.6), em outras línguas. O próprio título em francês Jeux interdits em relação a sua tradução em português, já aponta este uso dos termos. Não interessa aqui a vasta discussão sobre este tema, É somente colocado em questão para destacar que se usará aqui o termo jogar sem distinção em relação ao brincar. Porque o que se quer evidenciar é, como já foi dito acima, as formas como as duas crianças percebem e lidam com o mundo à sua volta, como habitam este mundo.

Fig.3: Na mesa de jantar. 


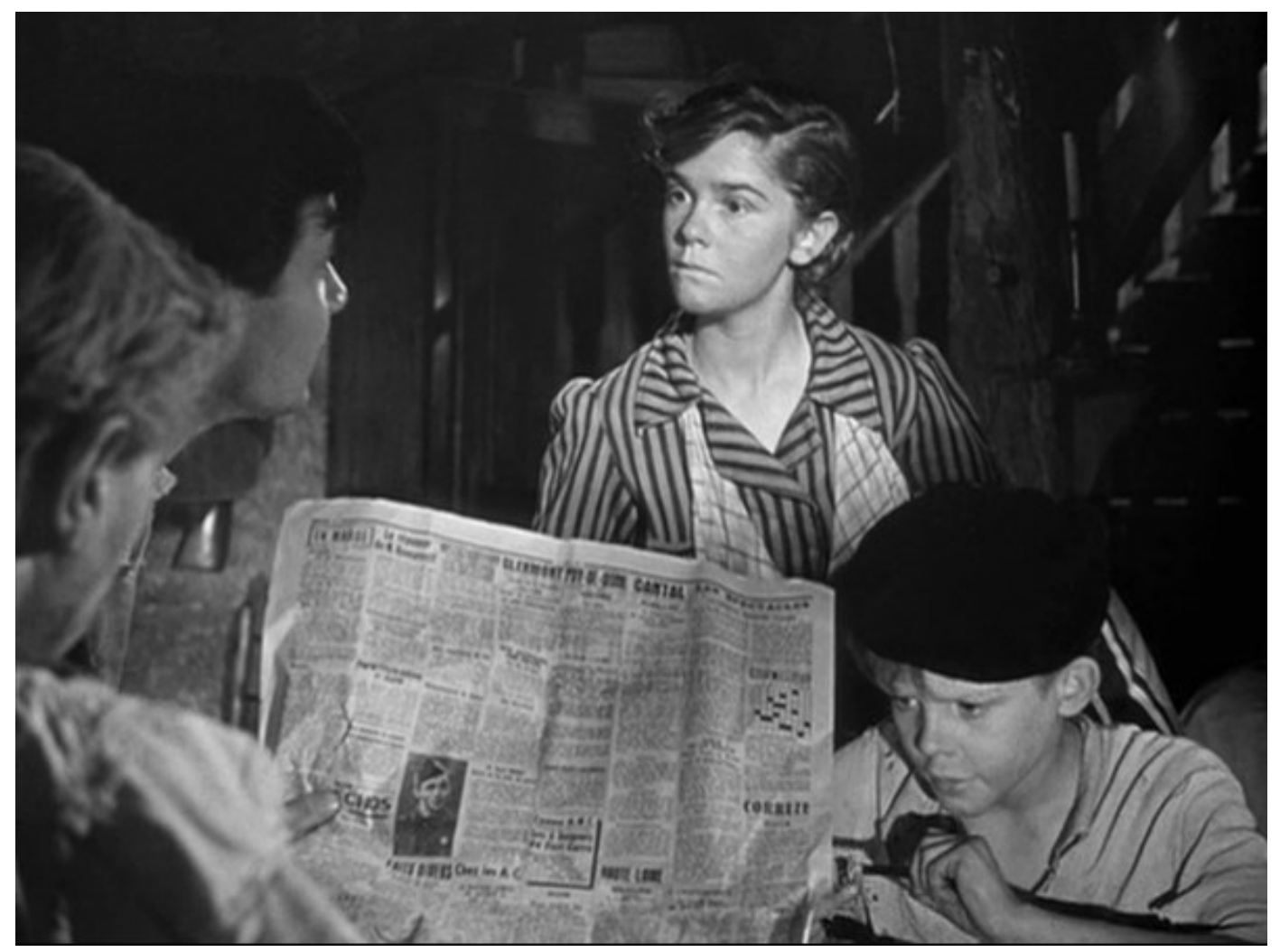

Fonte: http://worldscinema.org/2015/05/rene-clement-jeux-interdits-aka-forbidden-games-extras1952/>. Acesso em: maio/2015.

Na hora do jantar, o pai lê um jornal com as notícias da guerra e os adultos ao redor da mesa escutam. Um dos filhos está doente na cama, Paulette está no colo e Michel tentando fazer a lição. Paralela a esta cena, os dois trocam olhares e brincadeiras. O garoto cria várias caricaturas para entreter a menina (Fig.3). Assim que a filha vê uma foto do filho do vizinho (pelo qual é apaixonada) o assunto se concentra neles e na inveja em relação às medalhas de mérito na guerra. Michel ganha um tapa por não prestar atenção no exercício matemático. Depois de subir para o mezanino e deitar, Paulette chama por Michel e manifesta seu medo pela escuridão. Michel brinca com o claro-escuro a partir dos bombardeios, distraindo Paulette.

Nesta cena, pode-se observar como outro tempo se estabelece entre eles, diferente dos adultos, que marcam um tempo histórico da guerra e das relações vicinais na conversa. Assim uma das características deste jogo que se estabelece entre os dois é o tempo, que se diferencia dos adultos e configura algumas 
condições para o estabelecimento de um mundo particular. E na configuração deste tempo, a gestualidade compõe os sentidos. Mayor, ao falar da dimensão poética da narrativa do filme infere:

Do ponto de vista da construção da narrativa, esse território (de afetos e trocas) ${ }^{6}$ é demarcado por sequências protagonizadas por Paulette e Michel, cuja cumplicidade, estabelecida por um conjunto de códigos - olhares, segredos, silêncios se materializa no 'cemitério de animais', espaço privilegiado de encontro dessas duas solidões infantes, no qual elas se aventuram a ressignificar suas perdas e seu isolamento do mundo dos adultos (2007, p.98).

Ao que Mayor chama de códigos, aqui chamarei de gestos, no sentido de que não há algo fora dele mesmo, cuja condução não tem finalidade (AGAMBEN, 2007), cuja explicação - se é que há - está no interior dele mesmo. Pode-se pensar este jogo de cena sempre presente entre Michel e Paulette, como a composição desta gestualidade, constitutivas destes afetos intercambiáveis, entre personagens e entre personagens e espectador.

Outra questão é a constituição de uma espacialidade. A menina tenta enterrar o cachorro; depois de encontrar o padre carrega-o para um moinho e tenta cavar um buraco. Michel a encontra e, ao ajudá-la, tem a ideia do cemitério (Fig.4). Temos outra cena emblemática no estabelecimento do jogo.

Fig.4: Paulette e Michel no moinho.

\footnotetext{
${ }^{6}$ Inclusão minha.
} 


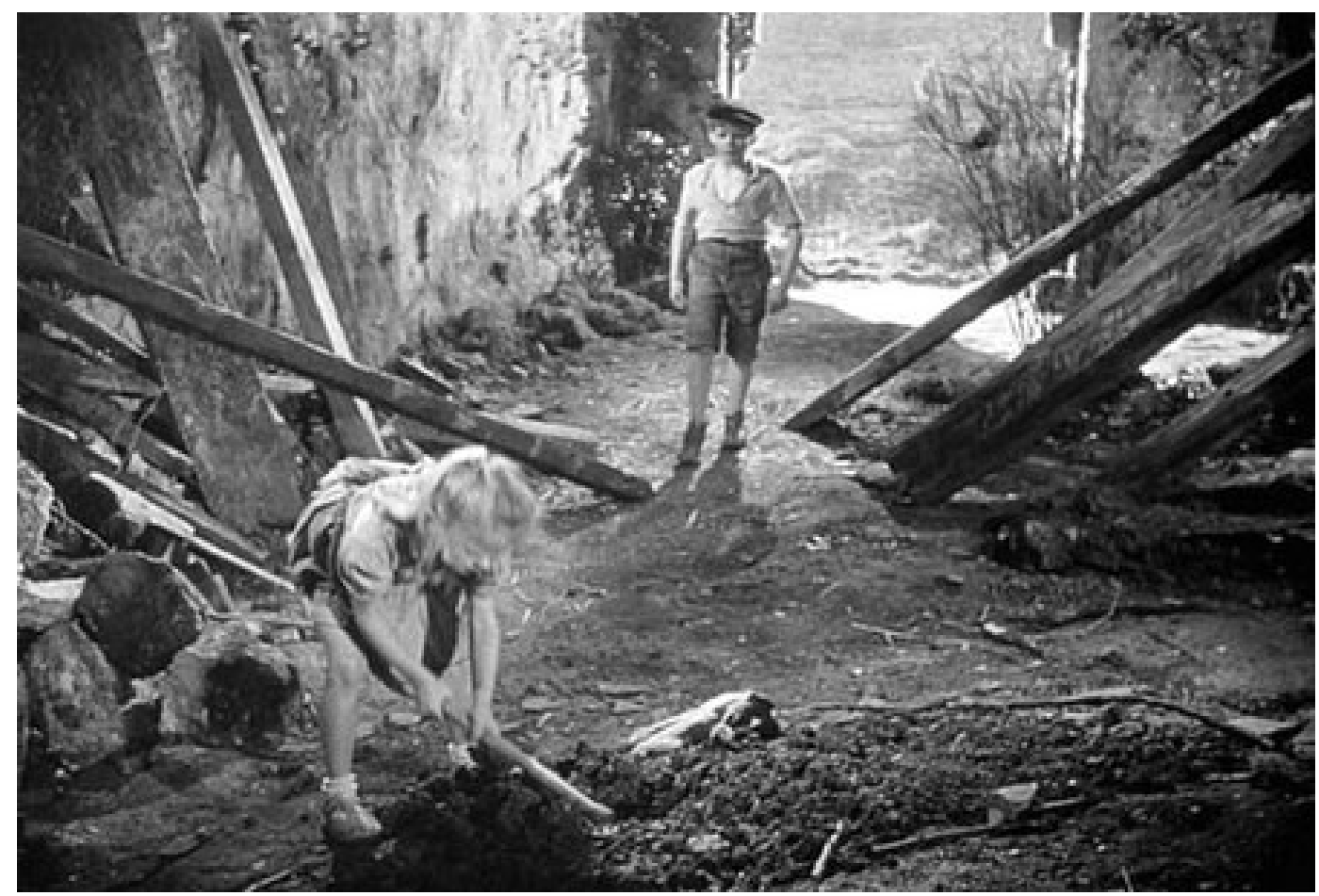

Fonte: http://thefifiorganization.net/janus/forbidden-games/>. Acesso em: maio/2015.

- O que é um cemitério? diz Paulette.

- É onde põem os mortos para que fiquem juntos- responde Michel.

- Porque os põem juntos?

- Para que não se aborreçam.

- O meu cachorro vai se aborrecer sozinho? Vamos colocar outro.

- Outro cachorro? Vai ser difícil.

Nesta hora eles olham para o mezanino: lá está o senhor prefeito, uma coruja que, segundo Michel, vivia cem anos. Sobe e pega uma toupeira morta ao lado da coruja, provavelmente sua caça.

Mostra a toupeira e a menina diz que não é suficiente, tem que ter outros animais.

- Gatos, ouriços, lagartos.

- Cavalos, vacas...

- E serpentes! diz Michel.

- Leões.

- Tigres.

- Pessoas... completa Paulette. Michel olha espantado e fala: 
- Se você quiser, podemos colocar cruzes a todos.

- Porque cruzes?

- Seus pais não Ihe ensinaram nada?

Fig.5: Michel ensina Paulette a rezar.

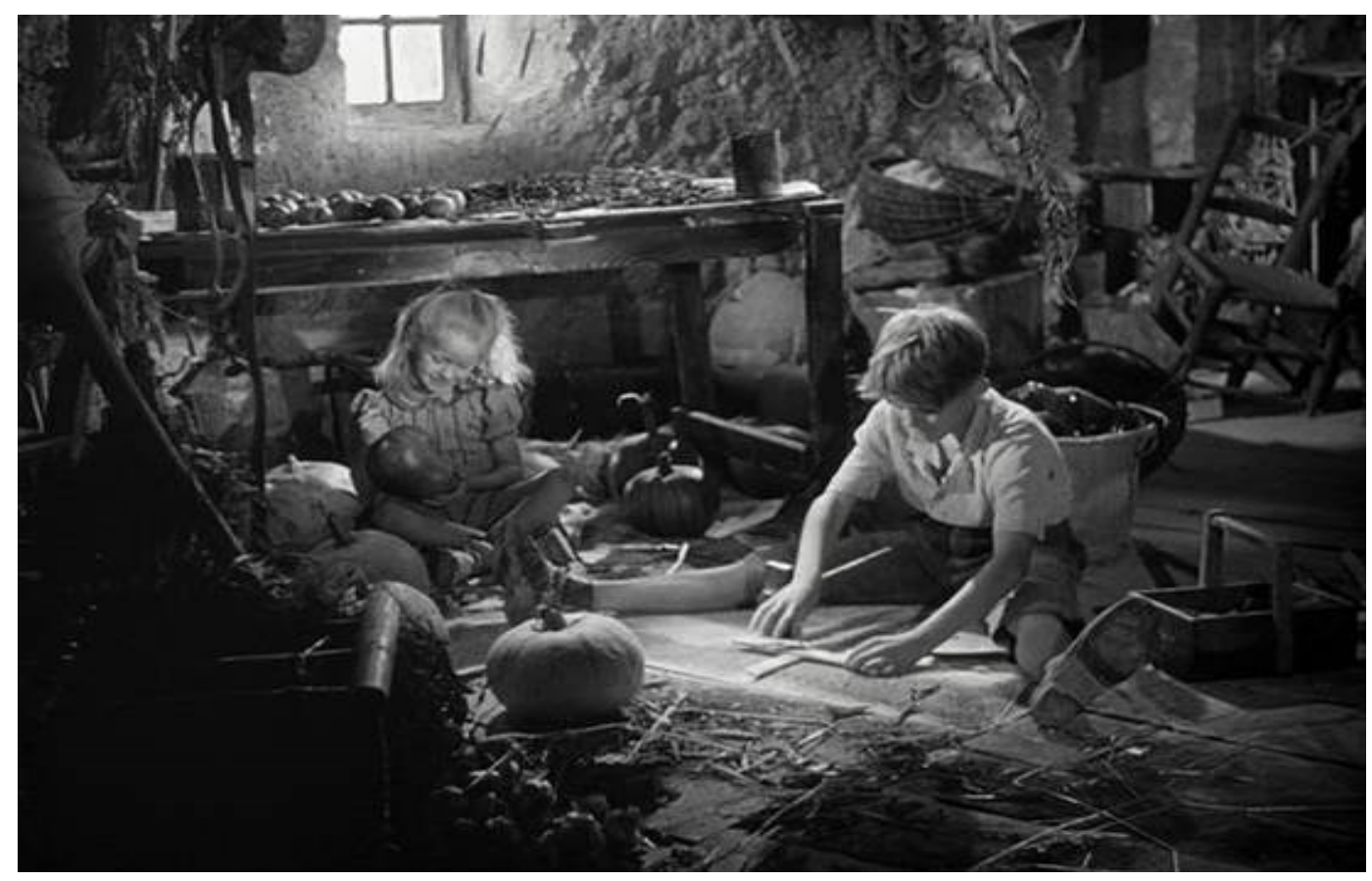

Fonte: $\quad$ http://www.myreviewer.com/DVD/152746/Forbidden-Games/152759/Review-by-StuartMcLean.>. Acesso em: maio/2015.

Estabelece-se como tabuleiro do jogo o espaço do moinho e, dentro dele, o que as crianças vão definir como cemitério. É para ele que as peças vão ser montadas e articuladas, é para ele que todas as estratégias no mundo dos adultos devem funcionar, é neste secreto território do jogo que a vida tem que acontecer. É sobre seu primeiro brinquedo, uma cruz, que Paulette coloca o seu colar quebrado. Nesta cena também se destaca o que já aparece em outras, que é a ausência de uma cultura religiosa por parte da menina. Michel sempre demonstra este estranhamento frente às perguntas da garota e se propõe a cumprir este papel catequizador, inclusive a pedido do padre, quando este descobre que ela não sabe rezar (Fig.5). Apesar de não fazer parte da linha de análise proposta aqui, pode-se pensar que este matiz religioso apareça como um contraponto entre cidade e campo, ou mesmo como uma sutil referência aos pais de Paulette como partidários 
do socialismo. Mostrar-se-ia, dessa forma, os diferentes grupos neste cenário de guerra e, neste caso, a ideologia de parte da resistência francesa aos nazistas.

Aliás, o fato de Michel saber rezar também o coloca em vantagem em relação à família. Na cena seguinte, em que é posto de castigo e fica sem jantar, descobrese que o irmão acidentado está morto e ele é chamado para rezar ao lado da cama. Nesta hora Paulette se aproxima e repete a frase que o padre the ensinou: que Deus o receba no seu paraíso. E inocentemente pergunta: está morto seu irmão? Vai fazer um buraco para ele? Michel incrédulo responde: está louca? ele é meu irmão! Assim a menina parece continuar no jogo, estar imersa nele. Isso vai ficando mais claro à medida que um e outro passam a ficcionalizar mais e mais os momentos vividos.

O filho do vizinho - com o qual a família de Michel vive às turras - volta da guerra. Eles mandam o garoto cortar comida para os coelhos para espiar o que eles conversam. Michel aproveita e rouba uns pintinhos, os mata e leva para Paulette. Por meio de uma história contada por Michel, ela que acredita que os bichinhos morreram naturalmente e este, por sua vez, só quer saber se ela está contente com os filhotes que vão se juntar a outros em seu cemitério.

Ana Godoy em seu livro $A$ menor das ecologias, volta sua atenção, em um dos capítulos, para o conto de Julio Cortázar, Bestiário. E ali ela diz sobre a personagem Isabel:

Para ela, a vida organiza-se entre as obrigações quanto ao tigre e as diversões. Encontrou um gafanhoto, os adultos oscilam entre o nojo e a descrição do belíssimo exemplar, mas Isabel pensa o que aconteceria se Ihe cortasse a cabeça ou se o colocasse no formigário. Isabel, criançapirata, "quer de tudo: coisas", lugares e pessoas que são os meios por ela explorados, "estudando e esquecendo-se das respostas", menina-formiga. (2008, p. 268).

É nesse paralelo, entre as obrigações no mundo dos adultos e o que elas vão inventando para si, que as crianças passam a dar outros significados às coisas, fazendo com que a própria guerra e as relações conflituosas de vizinhança fiquem em segundo plano. Talvez estes fatos e estas relações sejam por elas utilizadas e reordenadas, como para Isabel, em que "coisas, lugares e pessoas são os meios por ela explorados". Na missa fúnebre do irmão de Michel e no enterro no cemitério da 
aldeia, isso parece ficar mais claro. Passam a missa contando as cruzes dos quadros da Via Sacra:

- Estas não se podem tirar, observa Michel.

- Mas estas nem são bonitas, completa Paulette.

De repente se deparam com a cruz cintilante do terço do padre e Paulette diz:

- Esta estaria boa para uma abelha!

- Abelhas picam!

- Picam, mas não são más, retruca a menina.

Depois de o pai desconfiar de Michel no roubo das cruzes do coche funerário e chamá-lo à rua, este acusa os vizinhos Gouard e volta para o interior da lgreja e, junto com Paulette retomam o jogo, passando a cobiçar a cruz do altar. Já no cemitério parecem entrar em frenesi com a miríade de cruzes avistadas: essa ficaria boa para uma égua, e isso para uma pomba...um gato! Sim, mas bem gordo e aquela para uma girafa! Apontam ao fundo uma cruz alta e esguia. Enquanto os adultos discutem sobre o roubo das cruzes do coche, os dois não cessam de identificar os brinquedos para a sua brincadeira (Fig.6).

Fig.6: Paulette e Michel no cemitério. 


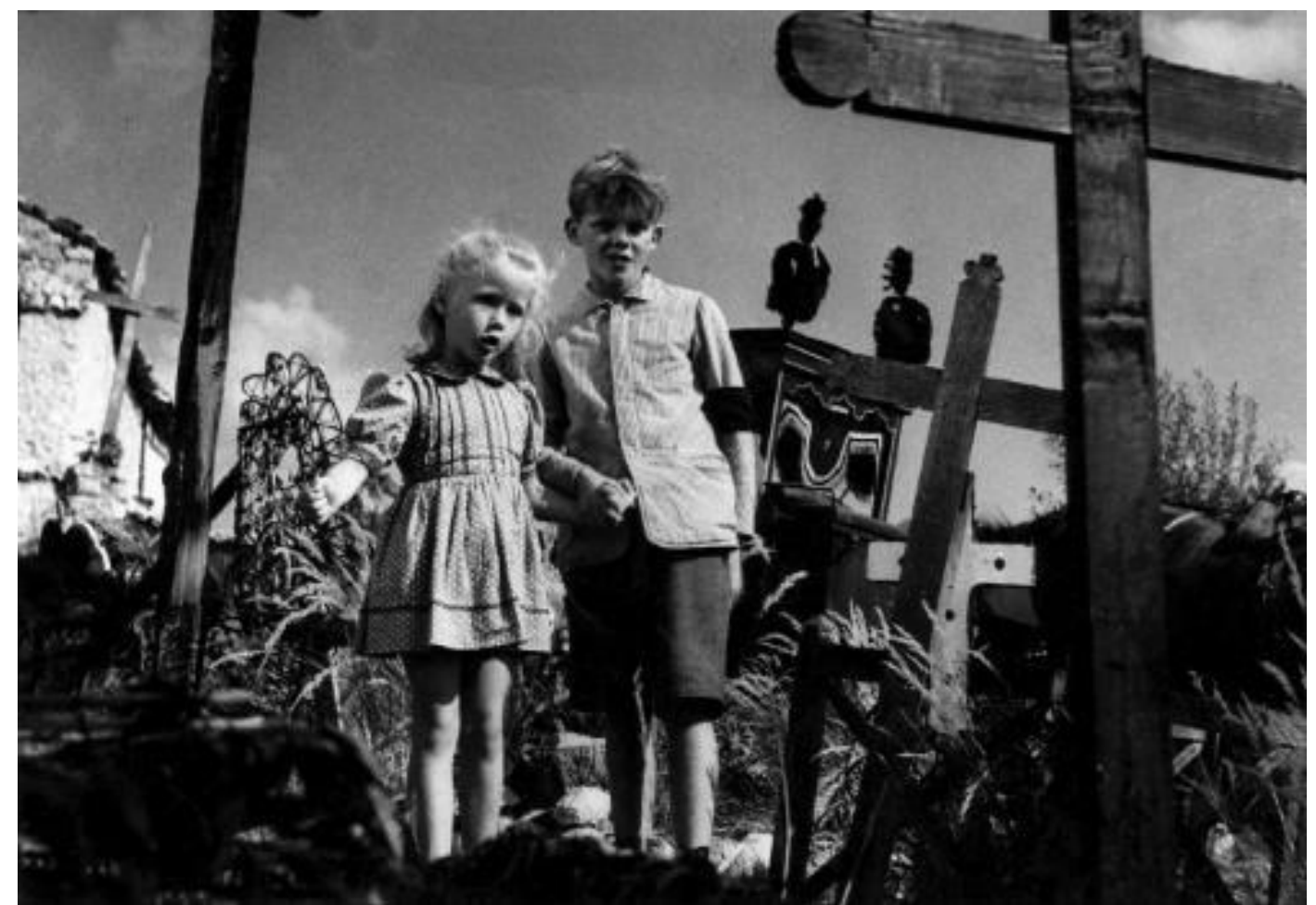

http://www.premiere.fr/Cinema/Photos-film/Photos-acteur/Georges-Poujouly-49827>. Acesso em: maio/2015.

Observa-se que o jogo se intensifica e inclusive o enquadramento, a constituição dos planos fílmicos se dá a partir dos olhares e das ações dos dois pequenos. É o olhar deles e, consequentemente o nosso, que vai para todo o tipo de cruzes, para todos os símbolos e rituais que portam estes objetos religiosos, mas que para Michel e Paulette são essenciais na constituição de seu território do brincar. Em outra cena no cemitério, por exemplo, Paulette cobiça a cruz da batina do padre, porque a cruz é um brinquedo, e a brincadeira não cessa de acontecer:

O jogo das crianças não se confunde com o jogo dos adultos. Suas perguntas são de outra ordem. Como isso funciona? Como funciona o formigário em relação ao gafanhoto? $\mathrm{E}$ as formigas pretas em relação às vermelhas? Como funciona o tigre em relação à casa? Haveria um tigrinho no formigário? (GODOY, 2008, p. 269).

Se há mais cruzes, precisa-se de mais animais mortos; se há mais animais mortos, precisa-se de mais cruzes, para a felicidade de Paulette e a de Michel, que quer agradá-la. E as questões das crianças vão se adensando e se distanciando de 
um tempo e espaço dos adultos. Há uma maravilhosa cena na qual os adultos estão à mesa discutindo sobre o roubo das cruzes do carro funerário.

Fig.7: Michel e Paulette eescrevendo as etiquetas para os animais de seu cemitério.

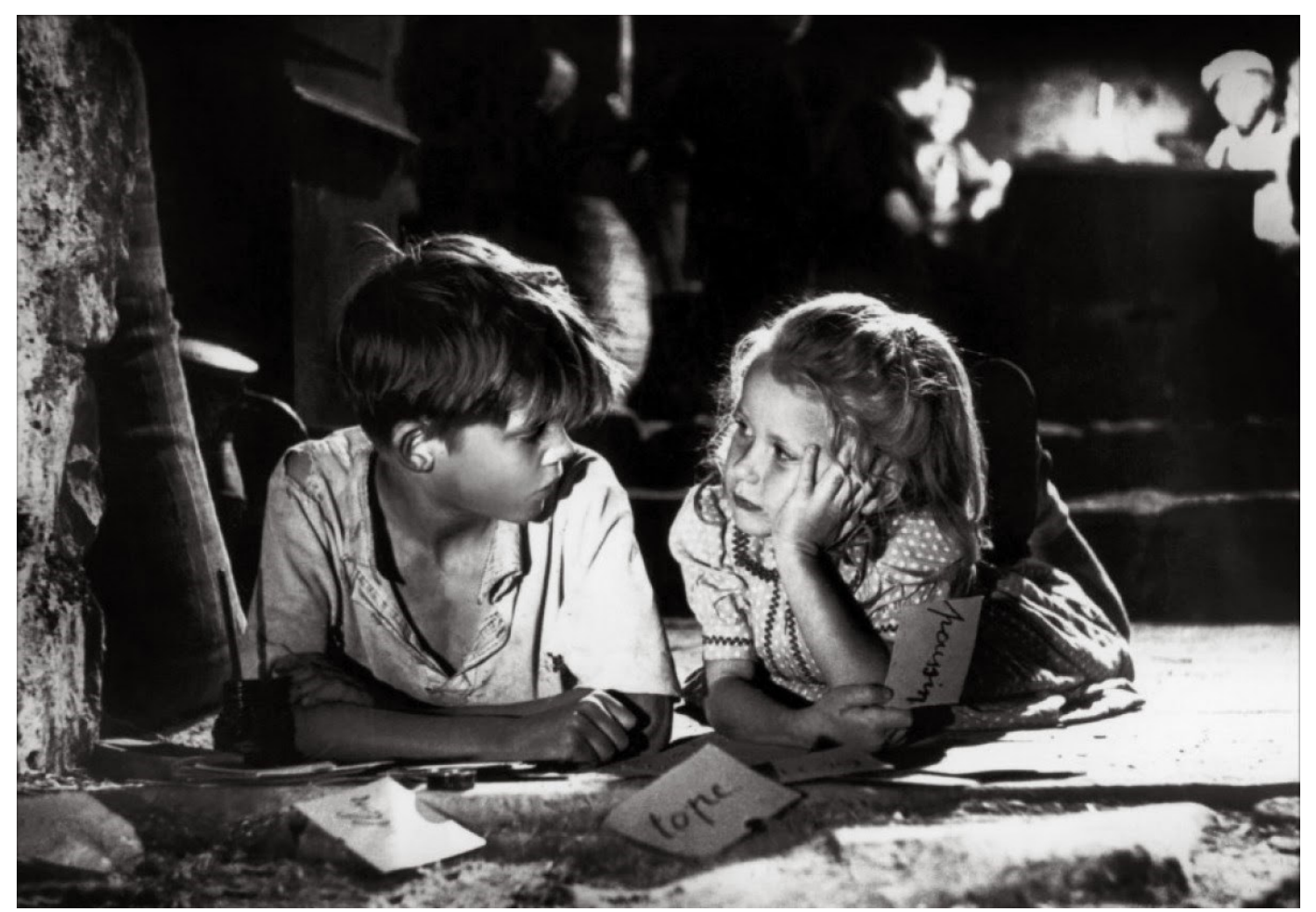

http://sigacena.blogspot.com.br/2014/02/brinquedo-proibido-de-rene-clement-jeux.html>. Acesso em: maio/2015.

A câmera faz um movimento descendente, um plano sequência que fecha nas crianças fazendo etiquetas escritas para os animais de seu cemitério: pintinhos, pronuncia Paulette, e a câmera em outras cartelas como Jock, minhoca, grilo.(Fig.7) Paulette acompanha uma barata caminhando e pergunta o que é aquilo e se morde. Como que a perguntar, como aconteceu com a abelha, se o bichinho é bom ou mau, o que parece ter se tornado uma regra importante para decidir se algum ser vivo poderia ser morto intencionalmente ou não. Michel esmaga a barata com o lápis e, diante da indignação da menina: não deve matá-la! Responde: não fui eu, foi uma bomba! Está louca? O menino traduz na forma de um bombardeio sua própria percepção da guerra: se queres enterrá-los, tem que estar mortos. E apesar de querer agradar Paulette esta abomina seu ato, no entanto exige sua 
cumplicidade pedindo pela cruz do altar do padre, a maior e mais bonita delas, que como símbolo icônico cristão, para ela, nada significa. E a menina diz:

- Eu sei onde há cruzes.

- Onde?

- No cemitério.

- Você não tem medo?

- Por quê?

- E se os mortos vierem nos puxar os pés? Diz Michel assustado.

Os dois se arriscam na aventura do cemitério dos adultos e na volta, com o carrinho de mão cheio de cruzes, os fachos de luz e sombra trazem novamente a realidade da guerra:

- Está com medo, diz Paulette.

- Não, e você?

- Não. Quer que eu cante? Diz a menina assustada.

- Se quiser...completa Michel.

Ambos olham para cima e veem a luz dos bombardeios, como fogos de artifício. Rapidamente Paulette passa a cantar, quase que em desespero e grita: - É preciso jogar-se no chão! Ao que Michel responde: - Eles não podem nos ver, vamos rápido. Há na luz dos bombardeios e nas sombras, possibilidades para o mundo paralelo de Michel e Paulette:

o jogo consiste em dissimular para manter sob controle e evitar as ameaças e os perigos. Jogo sob o qual toda sorte de violência se faz: surras, ameaças mudas, intimidações, lamentos sussurrados, imprecações. (GODOY, 2008, p. 269).

O jogo entre os dois os coloca em outro território, estabelece uma narrativa que os desloca da própria guerra e seus desdobramentos, mantém estas ameaças do mundo adulto sob controle ou, ao menos, lhes confere um papel neste jogo com o qual se pode lidar. Pode-se lembrar do filme O labirinto do fauno (2006) de 
Guillermo del Toro, no qual a menina Ofelia vive obedecendo e cumprindo as regras de um universo fabuloso, em busca de seu reino no submundo. No entanto é a Guerra Civil Espanhola que atua neste contracampo do jogo do qual ela participa. Todavia a menina transita entre um e outro mundo como se fossem um só, e ela programa seus passos sem evitar nenhum, nem outro.

Outra regra é esboçada na cena acima: tem de estar mortos para serem enterrados, ou seja, para que a brincadeira continue - mas tampouco podem ser intencionalmente mortos e nem podem ser maus - como já se sabe. Em Brinquedos e jogos (2002), Benjamin aponta uma importante lei no universo dos jogos: a repetição. E afirma:

\begin{abstract}
Sabemos que para a criança ela é a alma do jogo; que nada a torna mais feliz do que o "mais uma vez". (...) Para ela, porém, não bastam duas vezes, mas sim sempre de novo, centenas de milhares de vezes. (...) A criança volta a criar para si todo o fato vivido, começa mais uma vez do início. A essência do brincar não é um "fazer como se", mas um "fazer sempre de novo", transformação da experiência mais comovente em hábito. (2002, p. 101-102).
\end{abstract}

Dessa forma, para as duas crianças, a brincadeira é infinita, só se reelabora a partir de algumas regras que vão sendo construídas no percurso. $E$ ela não pode parar porque, como já vimos, as perguntas são de outra ordem, e só são possíveis neste "fazer sempre de novo". Neste sentido o suposto cemitério não é um território estático e nem a representação de um mundo adulto. Ele é em si mesmo o centro maquínico deste jogo, que demanda ações e execuções para além deste espaço, que permitem com que Paulette e Michel, assim como a Isabel do Bestiário, vençam seus medos. É no cemitério, e a partir dele que Paulette e Michel dizem o tempo todo o que fazem ou tentam fazer, exploram "os meios, por trajetos dinâmicos," e traçam "o mapa correspondente" (DELEUZE, 2011, p. 83). Assim tudo é movimento e deslocamento na constituição deste jogo.

Fig.8: O cemitério dos animais no moinho. 


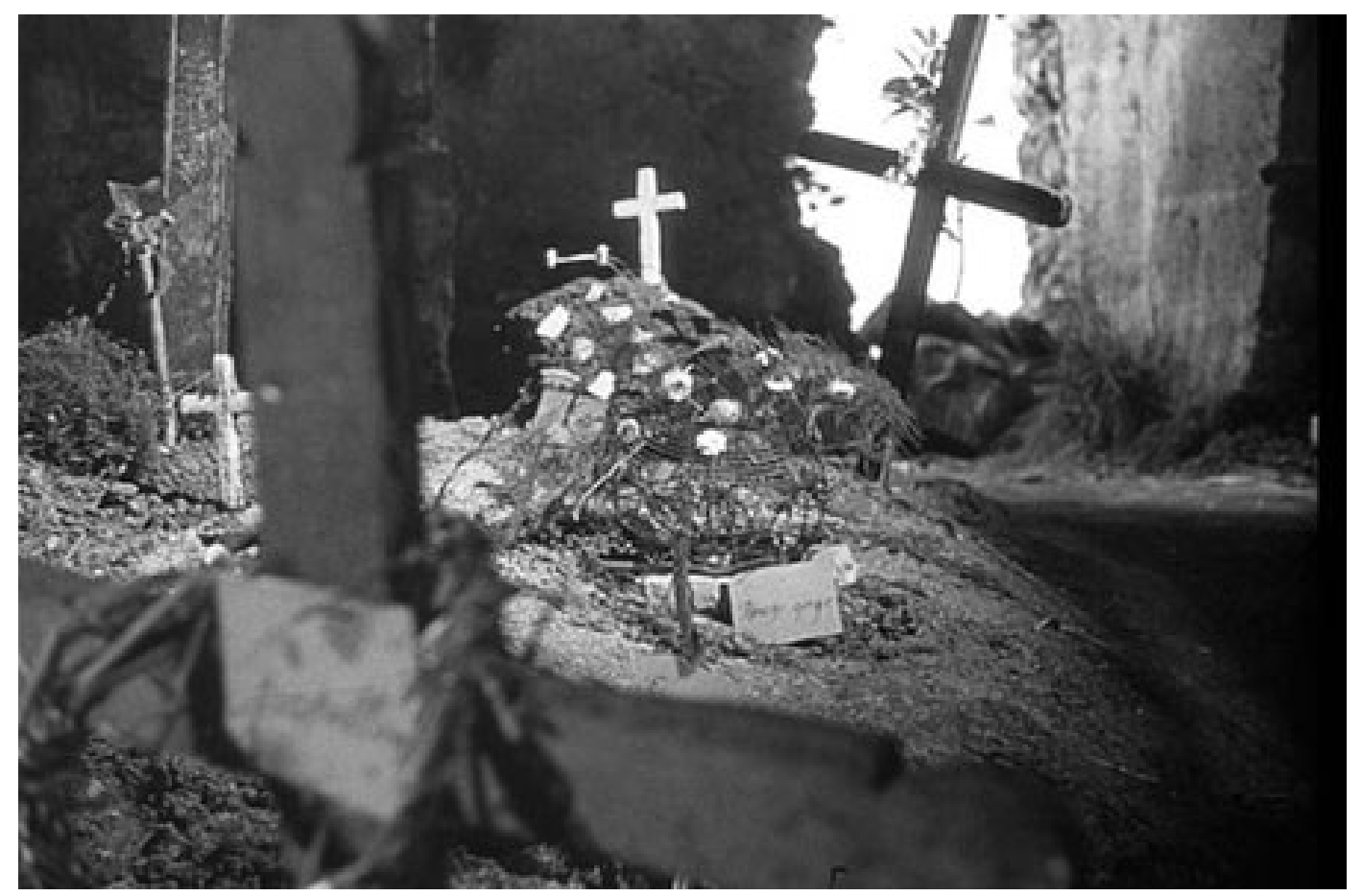

Fonte: http://thefifiorganization.net/janus/forbidden-games/>. Acesso em: maio/2015.

Quando a família de Michel descobre que foi o garoto que roubou as cruzes ele, com medo do castigo paterno vai se esconder no moinho abandonado. Nesta cena, a câmera faz um travelling por sobre o montículo do cemitério (Fig.8). As montanhas e as cruzes de diferentes tamanhos e formas, cada qual com sua plaquinha: Jock, o cachorro, a minhoca, o passarinho, o pintinho... Michel sentado come uma maçã e admira sua obra. No texto A infância em Berlim por volta de 1900, Walter Benjamin fala dos armários de sua casa e das suas gavetas: "cada pedra que eu achava, cada flor colhida, cada borboleta capturada, já era para mim começo de uma coleção, e tudo o que, em geral, eu possuía, formava para mim uma única coleção." (1987, p.24).

O cemitério das crianças, além de lugar primordial do jogo, também funciona como um acervo, uma coleção tão cuidadosamente acumulada especialmente por Michel para Paulette e cultivada pelos dois. Quando o garoto, que está escondido, vai visitar a menina e ela pergunta se o lugar está bonito, ele responde: Estão todas as cruzes e também as placas. Eu coloquei algumas pedras. Estão todos os animais e as flores. Cacos de louça, caramujos... No terreno infindável das cruzinhas há um 
"fazer sempre de novo", portanto um arranjo insistente de pequenas coisas descobertas.

Fig.9: Michel e o Senhor Prefeito, a coruja.

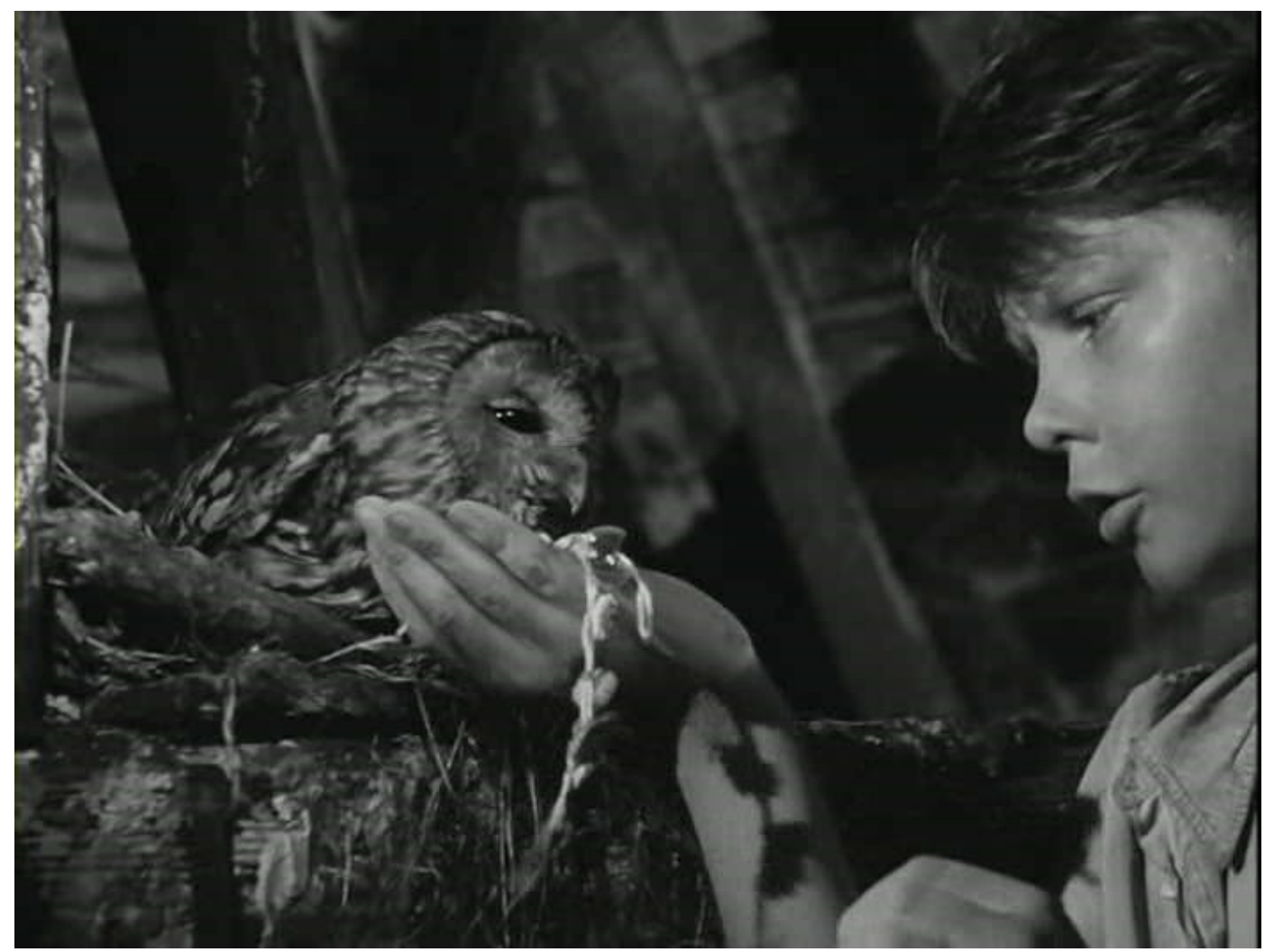

Fonte: http://m.blog.daum.net/007happy/13392696>. Acesso em: maio/2015.

Contudo, na manhã seguinte o pai de Michel descobre seu esconderijo e ao mesmo tempo os policiais chegam à propriedade. O que parecia ser uma denúncia pelo roubo das cruzes, revelou-se ser uma busca para levar Paulette a um orfanato. Michel negocia com seu pai o lugar onde estão as cruzes em troca da menina ficar com eles. O pai não cumpre com a palavra e enquanto a menina é levada, ele vai ao moinho e destrói o pequeno cemitério. Sobe no mezanino onde está o Senhor Prefeito - a coruja - e prende o colar de Paulette ao seu lado dizendo: Tome. Guarde-o por cem anos, como que a garantir que o jogo possa ser retomado, que a fábula apenas está em suspensão (Fig.9). A cena corta para Paulette que está em uma estação de trem aguardando. A menina acha que avistou o amigo e, pronunciando seu nome, segue em meio à multidão. Ao achar que "a vida é jogo", ambos lidam com o imponderável e ao mesmo tempo o intolerável de suas 
existências e parece ser esta repetição, esta invenção a única que traz algum sentido. Como escreveu Benjamin, ao falar de seu jogo mais saudoso, o jogo das letras:

O que busco nele na verdade, é ela mesma: a infância por inteiro, tal qual a sabia manipular a mão que empurrava as letras no filete, onde se ordenavam como uma palavra. A mão pode ainda sonhar com esta manipulação, mas nunca mais poderá despertar para realizá-la de fato. Assim, posso sonhar como no passado aprendi a andar. Mas isso de nada adianta. Hoje sei andar; porém, nunca mais poderei tornar a aprendê-lo. (1987, p.105).

No caso de Paulette e Michel, a contingência da própria guerra os afasta daquele jogo, pois interrompe o percurso em comum. Para nós, adultos, talvez seja de uma infância enquanto jogo e invenção que tenhamos nos afastado e com a qual tenhamos rompido.

\section{KAREN CHRISTINE RECHIA}

Doutora em Educação. Professora do Colégio de Aplicação - CA/CED/UFSC. Atua também na área de audiovisuais, com produção, roteiro e pesquisa. Membro da Rede Internacional de Pesquisa: Imagens, Geografias e Educação e do LEHCA Laboratório de Ensino de História do CA.

\section{REFERÊNCIAS}

AGAMBEN, G. Profanações.Trad.: Selvino José Assmann. São Paulo: Boitempo, 2007, $95 \mathrm{p}$.

BENJAMIN, W. Rua de mão única. v. 2. 2. ed. Trad. Rubens Rodrigues Torres Filho e José Carlos Martins Barbosa. São Paulo: Brasiliense, 1987, 277 p.

BENJAMIN, W. Reflexões sobre a criança, o brinquedo e a educação. Trad. Marcus Vinicius Mazzari. São Paulo: Editora 34, 2002, 171 p..

BRINQUEDO PROIBIDO. Direção: René Clément. França: Aurora, 1952. 1 dvd (86 min.): DVD, son., p\&b.

DELEUZE, G. Crítica e Clínica. Trad. Peter Pál Pelbart. 2ª.Ed. São Paulo: Ed. 34, 2011, 208 p..

GODOY, A. A menor das ecologias. São Paulo: Edusp, 2008, 333p. 
JARDIM, C. S. Brincar: um campo de subjetivação na infância. São Paulo: Annablume, 2003.

MAYOR, A. L. A. S. Jogos interditos da infância: solidão e poesia em Brinquedo proibido, de René Clément. In: FRESQUET, A. et al. (Org.). Imagens do desaprender: uma experiência de aprender com o cinema. Rio de Janeiro: Booklink; CINEAD-LISE-FE/UFRJ, 2007, 195 p.

O LABIRINTO DO FAUNO. Direção: Guillermo del Toro. México, Espanha, Estados Unidos: Warner Bros Pictures, 2006. 1 dvd (112 min.): DVD, son., color.

TEIXEIRA, I. A. C. T.; LARROSA, J.; LOPES, J. de S. M. A infância vai ao cinema. Belo Horizonte: Autêntica, 2006, 254 p.

SILVA, F. C. T. da. Pela vida dos outros. Disponível em: http://www.revistadehistoria.com.br/secao/capa/pela-vida-dos-outros. Acesso em: maio/2015. 